\title{
Pollution Havens and the Trade in Toxic Chemicals: Evidence from U.S. Trade Flows
}

\author{
By \\ John P. Tang \\ ANU Working Papers in Economics and Econometrics \\ \# 623
}

February 2015

ISBN: 0868316237 
Pollution Havens and the Trade in Toxic Chemicals: Evidence from U.S. Trade Flows

\author{
John P. Tang*
}

Australian National University

\begin{abstract}
National registries of toxic chemical emissions and facilities are increasingly used to raise public awareness of potential health hazards in local areas, but an unintended consequence may be the offshoring of production to less regulated countries. Using disaggregated U.S. trade data, this study examines the impact of registry listing on subsequent bilateral trade flows. Estimates from a difference-in-differences model indicate a significant shift toward imports from poorer countries following registry listing. Assuming that environmental protection is a normal good, this result suggests the emergence of pollution havens due to more stringent U.S. environmental regulation.
\end{abstract}

Keywords

pollution haven, environmental Kuznets curve, production offshoring, Toxics Release Inventory, pollution release and transfer register, Porter hypothesis

\footnotetext{
* Research School of Economics, 26 LF Crisp Building, Acton ACT 2601, Australia. Email: john.tang@anu.edu.au. The author would like to thank Randy Becker, Ann Carlos, Barry Eichengreen, James Fenske, Joan Hamory, Daniel Hicks, Ian Keay, James Markusen, Gary Richardson, and two anonymous referees for helpful suggestions.
} 


\section{Introduction}

Do changes in environmental regulation affect where pollution-intensive goods are produced? Differences in environmental policy coupled with trade liberalization may lead to the emergence of pollution havens, with polluting activity relocating to areas with less stringent regulation (Jaffe et al 1995, Copeland and Taylor 2004, Brunnermeier and Levinson 2004, Taylor 2004). Less clear is whether changes to environmental regulation itself have a similar impact on trade patterns, with production moving off-shore in response to mandated restrictions, heightened scrutiny, and financial considerations.

This paper examines American trade in toxic chemicals, specifically those designated as toxic by the U.S. Environmental Protection Agency’s Toxics Release Inventory (TRI) program. Following the 1984 industrial accident at a Union Carbide plant in Bhopal, India that killed nearly four thousand people within days and poisoned an estimated half a million in the following years, the United States Congress passed the Emergency Planning and Community Right-to-Know Act (EPCRA) two years later (Broughton 2005). The act required domestic industrial facilities to report to TRI the quantity of releases and transfers of certain toxic chemicals. These data are made available to the public under the premise that this information creates incentives for companies to improve their chemical management and reduce toxic releases. TRI data collection began in 1988 with 332 chemicals listed as toxic and has increased coverage to the current 683 chemicals and chemical categories. ${ }^{2}$

This study examines whether the implementation of the toxic chemicals registry program affects trade flows, and if so, how. While the intuition behind this question is straightforward in that increased domestic regulation in a globalized market can lead to increased imports as substitutes for domestic output, identifying a causal relationship from actual trade patterns is much less so. This owes to difficulties in mapping between regulation and economic activity, which are usually measured differently, and isolating the regulatory effect from other confounding factors like location- or time-specific trends.

Besides seeing whether trade patterns change, there is the narrower issue of whether toxic chemical imports are disproportionately sourced from less regulated jurisdictions, a phenomenon commonly known as the pollution haven hypothesis. This issue is controversial in part because it is not obvious that poorer countries, given their factor endowments, would have a comparative advantage in producing capital intensive goods like chemicals despite the common perception that such countries are more likely to host dirty industries given lax environmental standards.

\footnotetext{
${ }^{2} \mathrm{http}: / / \mathrm{www}$ 2.epa.gov/toxics-release-inventory-tri-program/tri-listed-chemicals
} 
Furthermore, environmental regulation may induce technological improvements to domestic manufacturers and allow them to produce more efficiently, thus mitigating adverse impacts from increased costs and scrutiny.

To analyze the trade of TRI chemicals over the past two decades, this paper uses bilateral trade data derived from records collected by U.S. Customs and Border Protection and processed by the Foreign Trade Division of the U.S. Census Bureau. These data are disaggregated at the Harmonized Schedule ten-digit level and comprise all trade in chemicals between the years 1989 and 2006 for 180 trade partners. The highly detailed nature of these data provide a methodological advantage in that, unlike existing studies of trans-national pollution havens, economy activity is observed at the commodity level instead of industry or subsector and thus corresponds to the individual chemicals listed on the TRI. This mitigates concerns regarding the composition of an industry's output, some of which may be pollution-intensive and subject to regulation while others are not.

Commodity disaggregation also allows comparison of the listed chemicals to those not subject to regulatory change, which can be used to control for pre-existing trends and comparability between chemicals. The analysis uses a difference-in-differences least squares regression model to identify an average treatment effect on imports before and after a chemical is listed on TRI, with the identification strategy further sharpened by variation across a panel of chemicals and different years of registry listing. Differences among trade partners, such as distance, trade barriers, and regulatory stringency, are accounted for by direct measures of shipping costs, paid duties, and per capita income, respectively.

The results from the regression model indicate that overall imports of chemicals listed on TRI do not significantly change compared to all other chemical imports; however, they are disproportionately sourced from poorer countries after listing. At the same time, I find a statistically significant fall in exports of listed chemicals, which may proxy for domestic output, thus suggesting that the TRI program may increase foreign production among developing economies at the expense of domestic manufacturers. In other words, this points to the creation of pollution havens from environmental regulation.

The remainder of the paper is outlined as follows. Section 2 reviews existing research relating to trade and environmental regulation as well as the historical background of the TRI program. Section 3 describes the hypotheses, data, and empirical framework used for analysis. Section 4 presents the results, and section 5 concludes with a discussion of the findings. 


\section{Existing Scholarship and the Toxics Release Inventory}

There is an extensive and growing literature on the relationship between trade and the environment, with a number of possible impacts. Increased trade has the potential to worsen environmental quality if the general scale of industrial activity also rises commensurate with economic growth; this is known as the scale effect (Antweiler et al 2001, Grossman and Krueger 1993). Over time, however, an economy's sectoral composition may change as the country exploits its comparative advantage; thus, those with greater relative endowments of capital will produce more capital-intensive goods, so depending on the pollution intensity of production overall pollution levels may rise or fall (Jaffe et al 1995). Regulation plays a role if environmental quality is a normal good, so as an economy becomes wealthier, public demand for clean air and water increases and the government responds with increasingly stringent controls on polluting activities, at which point firms may adopt cleaner production technologies, substitute away from more toxic inputs, or use pollution abatement equipment (Wheeler 2002). In early stages of development the converse may hold, with pollution increasing as economies shift away from agarian and labor-intensive production to more industrial, capital-intensive activities.

Numerous studies have examined whether this inverse-U relationship between per capita income and pollution, known as the environmental Kuznets curve (EKC), holds across a variety of pollutants and regions. In their study of the possible effects of NAFTA on Mexico and the United States, Grossman and Krueger (1993) find that Mexico at the time was at a level of per capita income where further increases in income would likely lead to increased demand for environmental protection. In addition, they find that freer trade would likely reinforce Mexico's comparative advantage in labor intensive manufacturing, which tends to be less pollution intensive. As a result, they conclude that increased trade may improve the Mexican environment as a whole, in contrast to the concerns of environmental groups at the time. Similarly, Antweiler et al (2001) model and estimate the scale, composition, and technique effects of international trade on sulfur dioxide concentrations and find that free trade would improve global environmental quality. Looking at seven different pollutants and their environmental outcomes, Frankel and Rose (2005) find that trade is beneficial to the environment on a few measures, has no effect on others, and potentially has a detrimental effect on one (carbon dioxide).

Other scholarship has been more critical and nuanced, with Hettige et al (2000) noting the lack of improvement in industrial water pollution for countries with middle income status or higher, although pollution intensity as a share of output declines with increased income. Stern (2004) finds that developing countries may 
adopt higher regulatory standards faster than wealthier ones, while Birdsall and Wheeler (1993) find that the EKC holds for more protectionist countries and depends on the period of analysis, with lower pollution intensity in the 1980s than the previous decade. On the issue of the dynamic interaction between regulation and cleaner technology, Porter and van der Linde (1995) suggest that higher standards may induce firms to undertake greater innovation to offset the costs of compliance, leading to absolute advantages over firms in countries with weaker policies. Costantini and Crespi (2008) find support for the Porter hypothesis in their study of the energy sector, using a gravity model to show regulation leads to an increase in the export of environmental technologies from European Union countries. Similarly, in a study of five different manufacturing sectors, Costantini and Mazzanti (2012) show that environmental policies may increase green exports through more efficient production processes.

The variation in findings may owe to the different levels of aggregation and measures used in the analyses. For example, the effect on trade from environmental regulation as proxied by expenditures on pollution abatement depend on whether the unit of analysis is at the industry, county, or facility level (eg, Kalt 1988, Tobey 1990, Grossman and Krueger 1993, Becker and Henderson 2000, Ederington and Minier 2003, Levinson and Taylor 2008). Another form of regulation, pollution release and transfer registries (PRTRs), varies in coverage of chemicals and hazardous waste materials across national regimes and is used mainly by the mostly wealthy OECD countries. The non-comparability across countries and selection bias in participants make assessing the efficacy of PRTRs difficult, with some studies indicating little or no effect on industrial emissions or changes in trade between developing and developed economies (Hibiki and Managi 2010, Kerret and Gray 2007, Thomas and Fannin 2011). Notwithstanding the issue of trans-national waste shipping, many PRTRs cover materials used as production inputs and were motivated by domestic concerns with minimal regard to potential trade consequences.

The U.S. Toxics Release Inventory, which was the world's first national PRTR, illustrates this point. On 3 December 1984, over 40 tons of methyl isocyanate gas leaked from a Union Carbide plant in Bhopal, India, killing thousands within days and affecting hundreds of thousands in the years since. Shortly after, in January 1985, the EPA announced that 28 leaks of methyl isocyanate had occurred in the previous five years at a similar Union Carbide plant in Institute, West Virginia, and on 11 August 1985, that same plant experienced a chemical release that led to the hospitalization of 135 workers and nearby residents. These events are cited as being among the primary motivations for the federal Emergency Planning and Community Right-to-Know Act (EPCRA), which was 
signed into law in October $1986 .^{3}$

The EPCRA instituted four new reporting requirements for facilities within the United States that use, produce, store, or release certain specified chemicals. Among the four, EPCRA Section 313 requires affected facilities to submit to the EPA and the relevant state office annual reports of chemicals released into the environment or transferred off-site. The information is then compiled and made available to the public in the Toxics Release Inventory (TRI), with the first year of data released in June 1989. Facilities are required by law to report to TRI their toxic releases and transfers if the facility meets certain conditions. First, the facility must have 10 or more full-time equivalent employees. Second, the facility must be classified as a manufacturing facility (SIC 20-39) or be engaged in one of a number of non-manufacturing activities, with reporting extended to federal plants regardless of industry classification starting in 1993. Finally, the facility must manufacture, import, process, or otherwise use any of the listed chemicals in amounts greater than the threshold quantities. For most of the chemicals covered by TRI, the critical annual thresholds are 25,000 pounds for the manufacture, import, or processing of a chemical, and 10,000 pounds for the mere use of a chemical, with over 20,000 facilities reporting on average per year.

At TRI's inception, 332 chemicals and chemical categories were subject to reporting. Through the years, chemicals have been added and deleted from the list with the current year covering 683 chemical entities. Besides basic information about the facility itself, for each of these chemicals meeting any of the above thresholds the facility is required to report: how the chemical is used at the facility; the maximum amount of the chemical at the facility at any one time during the year; releases in pounds of the chemical to the environment; transfers of the chemical to off-site locations (e.g., disposal, treatment and recycling facilities); on-site waste treatment methods related to the chemical and their efficiency; source reduction and recycling activities related to the chemical. This information is disseminated to the public via the EPA's TRI online database and other websites as well as local and national meetings held annually following the release of the latest year's statistics.

The basic premise behind TRI is that making this information publicly available creates incentives for companies to improve their chemical management and reduce toxic releases. The mechanism that is chiefly cited is community pressure on local facilities, although empirical research tends to focus on how consumers and investors influence companies through market signals. For instance, Hamilton (1995) finds that publicly-traded firms reporting to TRI experienced abnormal negative stock returns on the day following the release of the very first TRI

\footnotetext{
${ }^{3} \mathrm{http}: / / \mathrm{www}$. epa.gov/tri/
} 
data in June 1989. The effect was more pronounced for companies reporting a greater number of TRI chemicals and less for those with known Superfund sites, which are locations contaminated by hazardous substances and overseen by federal authorities. Both Konar and Cohen (1997) and Khanna et al (1998) find that, on average, a publiclytraded firm reporting to TRI experiences negative stock returns in the days following media coverage of a company's TRI emissions. In contrast, Hibiki and Managi (2010) find that the Japanese equivalent to the TRI program does not appear to penalize companies for the risk of toxic chemical releases, although their investment in pollution abatement increases. That said, the U.S. TRI program is often held up as a successful market-based solution that requires only reporting, not mandatory limits, and in terms of reported emissions the aggregate volume of releases and disposal for covered chemicals has fallen steadily in most years since the program began and as chemicals are added.

Interpreting these downward trends as a causal impact of regulation, however, may be problematic for a number of reasons. First, facilities are not required to report emissions when the chemicals are not listed, making it impossible to compare pre- and post-listing trends based on emissions alone. This problem of identification is exacerbated by the non-disclosure of firm production data to the public (and the EPA provides only broad ranges of values), as it is not obvious that changes in emission levels owe to changes in levels of domestic production, improved emissions capture, false reporting, gaming of reporting thresholds, overlapping regulation, or a combination of these. A number of studies have found that facilities under-report their toxic releases or limit emissions to just below the thresholds that would trigger a reporting requirement, which is known as threshold regarding (Bennear 2008, Koehler and Spengler 2007). Other studies have suggested that declines might be due to regulation of some of these chemicals under other federal and state programs or as a side-benefit of the regulation and abatement of non-toxic pollutants such as those covered under the Clean Air Act (Bui 2005, Koehler and Spengler 2007).

Even assuming that reduced emissions of listed chemicals indeed represent better management of their usage and transfer and possibly lower overall domestic production, the international dimension of increased regulation, specifically the substitution of imported chemicals, remains unaddressed. Furthermore, per the Porter hypothesis, separately examining the import and export flows of these chemicals may provide insight into the dynamic behavior of domestically regulated firms, which previous research suggests may change in their production efficiency (Costantini and Mazzanti 2012). This paper investigates the effect of TRI listing on a chemical's trade flows to see if 
production is being offshored, whether income differences with trade partners are a contributing factor, and if the net effect of regulation has had an adverse impact on imports and exports across all affected chemicals.

\section{Research Design: Data and Methodology}

The main hypotheses tested in the analysis are: 1) TRI listing is associated with increased gross imports; and 2) TRI listing increases the share of imports from poorer countries. Similar, but opposite effects should be observed in the export data, although if the Porter hypothesis applies, exports may increase with regulation as firms improve their production processes. Following Copeland and Taylor (1995), these possible outcomes are respectively known as the pollution haven effect and the pollution haven hypothesis, or more intuitively the weak and strong forms of the pollution haven phenomenon. The weak form hypothesizes that an increase in a country's regulatory stringency will, at the margin, result in a relocation of pollution-intensive industrial activity and be observed in increased imports and/or lower exports. The strong form hypothesizes that a disproportionate share of polluting-intensive production will be sourced from less regulated countries, which is proxied by income level per the environmental Kuznets curve. This effect may be mitigated by factor endowments and the capital intensity of the goods produced (Antweiler et al 2001).

Both questions are amenable to using detailed bilateral trade data and a difference-in-differences approach, which can be used to compare changes to import and export values for individual chemicals both prior and following TRI listing. This paper focuses on a panel of toxic chemicals that were added to the TRI list between the years 1989 and 2006 using publicly accessible data collected by the U.S. Census Bureau and disseminated by the National Bureau of Economic Research and the Center for International Data. ${ }^{4}$ By looking at changes to the TRI list, one can identify the direct treatment effect of TRI regulation, which is then compared to trade patterns of other chemicals unaffected by a change to their TRI status. Unlike the observed emissions data provided by TRI, which are available only when chemicals are listed, these trade data allow one to differentiate a policy effect from a general rise in trade or other unobserved or idiosyncratic factors. Furthermore, since the United States trades chemicals with countries that vary in income levels and regulatory stringency, controlling for these can provide evidence on whether increased domestic environmental protection has led to the creation of offshore pollution havens.

The data used in this study come from U.S. Customs and Border Protection administrative records, which are

\footnotetext{
${ }^{4} \mathrm{http} / / /$ cid.econ.ucdavis.edu/usix.html
} 
processed by the Foreign Trade Division (FTD) of the U.S. Census Bureau and then aggregated by trade partner and commodity. These annual series include all bilateral merchandise imports and exports at the ten-digit Harmonized Schedule (HS) classification system and contain information on current dollar value and for imports, their shipping and insurance costs and duties paid. Since some of the identified chemicals are imported but not exported by the U.S., results for imports and exports are separately reported. Import values include cost, insurance, and freight (CIF) prior to leaving foreign ports and exports are valued at the free alongside ship (FAS) value, which includes all transport and insurance charges incurred within the United States. ${ }^{5}$ Trade in chemicals falls under the two-digit HS codes of 28 or 29 , with those chemicals not identified by TRI listing making up the comparison group as described below.

To identify overlap between traded HS commodities and TRI listed chemicals, I match exact chemical names or their molecular equivalent between both databases. Of the current 683 TRI chemicals, over 200 were added or dropped between 1989 and 2006, with major changes taking place in the years 1994, 1995, and 2000. ${ }^{6}$ Within this period, there are exact name matches for 28 chemicals added to the registry in the import schedule, and of these 11 in the export schedule. The difference between the schedule owes to the more detailed information needed to assess tariffs for imports, although the commodity codes are mostly consistent between the two schedules. Furthermore, the overall number is limited primarily because many HS classifications, while highly detailed compared to industry classifications, nevertheless encompass multiple chemicals with at least one not on the TRI registry. The advantage to using exact name matches is that they allow for a clean comparison between treatment (TRI listing additions) and control (unaffected chemicals) groups, with the findings providing as a conservative estimate of the treatment effect. This direct mapping between the level of regulation and the observed outcome strengthens the identification of TRI's impact and to the author's knowledge no existing study has used a similar approach with these data sources.

The panel of TRI-added chemicals range from household products (e.g., cleaning fluids) to intermediates in or byproducts of industrial manufacturing (e.g., solvents, refrigerants); they also vary in their economic value, environmental hazard, and toxicity levels. ${ }^{7}$ For example, chlorodifluoromethane (aka, HCFC-22) is the most widely used chemical in the panel, although the chemical category of vanadium compounds has by far the most pounds of emissions. Formic acid is a chemical byproduct in the production of other chemicals like acetic acid and can be

\footnotetext{
${ }^{5} \mathrm{http}: / /$ www.census.gov/foreign-trade/guide/index.html

${ }^{6} \mathrm{http} / / / \mathrm{www} 2 . e p a . g o v /$ toxics-release-inventory-tri-program/changes-tri-list-toxic-chemicals

${ }^{7}$ For ranking of chemicals by toxicity, see http://scorecard.goodguide.com/env-releases/def/tep_gen.html.
} 
found naturally in some insect venom. The data appendix provides more detail about these chemicals, such as their health hazard rating and major trade partners over the period.

To test the hypotheses that chemicals added to the TRI list lead to increased imports and that a disproportionate share is sourced from less regulated countries, this paper estimates the following reduced form fixed effects regression model:

$$
\begin{aligned}
y_{i j t}=\beta_{0}+ & \beta_{1} \cdot x_{i i t}+\beta_{2} \cdot x_{2 j t}+\beta_{3} \cdot x_{1 t} \cdot x_{2 t}+\beta_{4} \cdot x_{4 i, j t}+\beta_{5} \cdot x_{5 j i t}+\varepsilon_{i t}, \text { where } \\
y_{i j t} & =\text { gross trade value for chemical } i \text { from trade partner } j \text { in year } t \\
x_{l i t} & =\text { TRI listing status for chemical } i \text { in year } t \\
x_{2 j t} & =\text { per capita income for trade partner } j \text { in year } t \\
x_{4 j t} & =\text { control variables for trade partner } j \text { in year } t \\
x_{5 j i t} & =\text { control variables for chemical } i \text { and trade partner } j \text { in year } t \\
\varepsilon_{i j t} & =\text { error term }
\end{aligned}
$$

Since the dataset comprises all bilateral trade for the U.S., I construct a balanced panel for each chemicaltrade partner pair, including zero values for years in which trade for a chemical from a country does not occur. The main variables of interest are the policy intervention variable $x_{l i t}$ and its interaction with trade partner per capita income $x_{2 j t}$. The cumulative effect of these two variables' coefficients can be interpreted as indicating whether the weak form of the pollution haven phenomenon obtains (i.e., the net TRI effect), while the coefficient on the interaction variable indicates whether the share of trade among partners changes following TRI listing.

Also included are a number of time varying control variables by country $x_{4 j t}$ (i.e., net terms of trade, national income level) and by country-chemical $x_{5 i j t}$ (i.e., import transit costs, duties) that may affect trade flows separate from environmental policies. Country-level statistics were obtained from the World Bank Group's World Development Indicators online database. ${ }^{8}$ I include an additional country and time varying indicator variable for OECD membership to proxy for institutional similarities and participation in selective multilateral treaties, including the 1992 Basel Convention that restricts the export of hazardous wastes to non-members (Thomas and Fannin 2011). ${ }^{9}$ All specifications include fixed effects for trade partner, year, and ten-digit HS chemical with robust standard errors reported in the tables.

\footnotetext{
${ }^{8} \mathrm{http}: / /$ go.worldbank.org/3SGLDH5V10.

${ }^{9} \mathrm{~A}$ list of OECD member countries and their accession dates can be found at http://www.oecd.org.
} 
Causal interpretations from difference-in-differences estimation are valid conditional on the ex ante comparability of the treatment and control groups prior to treatment as well as the exogeneity of the treatment on the observed outcome. For the control group of unaffected chemicals, the analysis uses all other traded chemicals either aggregated into a single series of trade values or as a panel of individual chemicals based on ten-digit commodity code. Both specifications include only chemicals with time consistent commodity codes in the period 1989 to 2006 to mitigate panel heterogeneity. To verify comparability between treatment and control groups, I run the full model specification on each cohort of added chemicals in the years prior to TRI listing (e.g., 1989 to 1993 for chemicals added in 1994). Cohorts that exhibit statistically significant differences in the pre-treatment period based on future TRI listing are excluded from the main analysis for both pre- and post-treatment years. As for exogeneity of treatment, no documentation from the U.S. EPA indicates foreign trade as a consideration in the decision to add chemicals; this is likely due to agency's jurisdiction being limited to American borders and the localized impact from the hazards of emissions.

\section{Results and Robustness Checks}

While the EPA reports that overall emissions for TRI chemicals have decreased since their listing, the trends for individual chemicals in the panel vary considerably. Table 1 lists the traded chemicals added to TRI between 1989 and 2006 and their average annual reported emissions and gross import values, with the latter separated for years before and after TRI listing. As the table shows, the majority of the chemicals had decreasing emissions during the years they were listed on TRI, including the three chemicals with the largest absolute emissions, corroborating the EPA's claims. Over the same period, however, most of these also had positive gross import growth and in the case of the largest chemical emissions, vanadium compounds, much higher growth compared to years when the chemical group was unlisted.

[Table 1]

To more robustly account for differences between chemicals and secular trends affecting trade, results from the difference-in-differences regression model are provided in the remaining tables. Tables 2 and 3 report estimates for the panel of TRI-added chemicals compared to the control groups of all other chemicals in aggregate or individual series, respectively, with annual gross import value by trade partner as the dependent variable. The first three columns in each table show the results from the pre-treatment period to indicate whether there were differences 
between the treatment and control groups. Across all three cohort groups, none exhibits statistically significant differences based on later TRI change, demonstrating the comparability of the two groups.

[Tables 2 and 3]

Results for each cohort and the full panel of chemicals are in the remaining four columns. In both tables, the coefficient for the TRI indicator variable (row 1) is positive, but statistically insignificant, while that for trade partner per capita income (row 2) is positive and significant. These suggest that on its own TRI listing has little effect on import volumes and that listed chemicals are imported more from other wealthy countries over the whole period, which may be expected given the capital intensity of chemical manufacturing. However, the interaction of the two variables (row 3 ) is uniformly negative and highly significant, indicating that in the years following listing, these chemicals are increasingly sourced from poorer countries. This is true despite a positive and generally significant coefficient on OECD membership, which imposes restrictions on the trade of toxic chemicals with nonmember countries.

To estimate the net TRI treatment effect, I perform a Wald test on the linear combination of the coefficients for the TRI listing and its interaction with per capita income variables calculated at the average trade partner income level of $\$ 14,858$ during the period. In the aggregate control group specification (Table 2), the net TRI effect is generally negative and significant, indicating a decrease in imports of listed chemicals following their registry inclusion. However, when disaggregated by individual chemical in the control group (Table 3), the coefficient is no longer statistically significant. Thus, while the estimates across specifications provide support for the strong form of the pollution haven phenomenon, i.e., higher share of TRI chemical imports from poorer countries following regulation, it is unclear whether there is an overall increase relative to other chemical imports because of listing.

Since the impact of TRI listing is likely to affect domestic production, which may correspond to the volume that is exported, the same regressions are used for gross export values in Tables 4 and 5. Separate analysis of gross exports may also provide evidence for or against the Porter hypothesis; that is, if regulation spurs technological improvements that increase production efficiency, exports may increase in contrast to predictions based on the pollution haven effect, especially given the length of the period of analysis. Note, however, that the number of exported chemicals with a TRI listing change are fewer in number than those imported, so the results between the two tables are not directly comparable. Furthermore, unlike the results for import values, the cohort of chemicals added in the year 2000 differs from both control group specifications during the pre-treatment period (column 3 ) and 
thus is excluded from the full panel analysis (column 6).

[Tables 4 and 5]

The main specification results differ between the two control groups, with a negative and statistically significant coefficient on the net TRI effect for the aggregate series in Table 4, similar with that for imports in Table 2, but insignificant for the individual chemical panel in Table 5. In both tables of export results, however, the interaction of TRI listing and trade partner per capita income is negative and significant, indicating that wealthier countries decrease their imports of listed chemicals following registry inclusion. Comparing the results from all four tables, one notes that the coefficient for the net TRI effect is negative for both imports and exports and generally larger in magnitude for the latter. An interpretation of this is that U.S. production (exports) and use (imports) may have decreased in response to TRI listing, with a more pronounced impact on production.

While the results across cohorts and for the full panel of chemicals indicate that TRI listing is associated with a relative increase in the share of imports from poorer trade partners, a potential concern is that their statistical significance is due to serial correlation in the time series data, thus creating a downward bias in the standard errors. Following Bertrand et al (2004), I check for their robustness by collapsing the years before and after treatment for each of the three cohorts into two periods and rerun the regression model. Note that this method is not applicable to the full panel of chemicals in a single regression since period (instead of year) fixed effects would overlap.

\section{[Tables 6 and 7]}

The robustness check results for both imports and exports are given in Tables 6 and 7, respectively, with the panel of individual chemicals used as control groups. Pre-treatment estimates are shown in the first three columns and the main pre- and post-treatment comparison in the remaining three. For imports, the net effect of TRI listing again is negative, but insignificant for all three cohorts, and the interaction of TRI listing with per capita income has negative coefficients for chemicals added to TRI in the years 1995 and 2000. Of these, the year 2000 cohort is statistically significant and thus consistent with earlier results that include the time series dimension; this cohort also includes the group of chemicals responsible for the largest amount of emissions, vanadium compounds. On the other hand, the chemicals listed in the year 1994 have a positive and weakly significant coefficient on the interaction term, suggesting the strong form of the pollution haven phenomenon may not obtain for those four chemicals.

For exports, the results have a clearer and more consistent interpretation. While the pre-treatment estimates for the 1994 cohort indicate differences between the treatment and control groups, those for the two other years do 
not. Estimates of their pre- and post-treatment periods show that TRI corresponds to a large and highly significant reduction in exports of listed chemicals, which is evidence in support of the pollution havens phenomenon and contrary to the Porter hypothesis. Taken together with the import results and the absolute increase in trade of listed and unlisted chemicals over the period, the earlier finding of a change in the composition of trade partners (i.e., increased sourcing from poorer countries) applies at least to a quarter of the chemicals in the full panel.

\section{Discussion and Conclusion}

While declines in reported emissions of TRI chemicals in the years following their listing may indicate that TRI is having its intended regulatory effect, the results from this paper's analysis suggest that some of these emissions may have relocated abroad, especially to poorer countries with likely lower environmental protection. Using a panel of 28 toxic chemicals added to TRI between 1989 and 2006, I find that registry inclusion is associated with a shift among trade partners toward those with lower per capita incomes. Unlike earlier studies that analyze the pollution haven phenomenon at the industry level, this study utilizes highly disaggregated trade data that allow matching the level of regulation to an observed economic activity. These estimates are sharpened not only through comparing pre- and post-TRI listing trade activity, but also by exploiting the variation between the TRI chemicals themselves, their different listing years, and multiple source and destination countries. Taken together, I find evidence supporting the pollution haven phenomenon among regulated chemicals for both imports and exports, even with potential efficiency improvements among among domestic producers due to TRI.

That said, these findings rely on a number of assumptions, in particular that per capita income is a good proxy for environmental protection and that trade flows are representative of overall production. To increase the precision of the estimates, one can identify changes in environmental protection among all U.S. trade partners such as their adoption of programs similar to TRI. However, even with critical assessments of the relationship between income and demand for environmental quality, pollution intensive activity does not appear to monotonically increase as countries become wealthier, and this paper's results illustrates this with evidence from both imports and exports of toxic chemicals. The results are also limited to a narrow set of chemicals with no information about the using or producing firms themselves, so it remains unclear what impact the regulation may have had on domestic production processes or the sector as a whole.

The findings can also be refined by using measures of actual output instead of trade flows, which are an 
imprecise proxy; unfortunately, due to firm confidentiality, such data are not available. In terms of approximating total production, however, trade flows are arguably a more representative measure of output compared to reported emissions given ongoing improvements to reduce environmental impact while maintaining production levels. Technological change along the lines of the Porter hypothesis further underscores this point as differences in production techniques between countries with strict or lax regulations may increase over time, so shifts in the sourcing of chemicals present unambiguous support for the pollution haven phenomenon. By showing that exports of listed chemicals decreases while imports do not, technological upgrading as a response to domestic regulation does not appear to be a major factor in explaining trade patterns.

Besides providing empirical evidence of a trade impact from environmental regulation, the results also highlight the utility of cataloging toxic substances and pollution intensive activities and disseminating these statistics to the public. Programs like TRI are increasingly adopted internationally, but remain highly variable in coverage and at present are mostly found in wealthier countries. One concern is that pollution release and transfer registers address a narrow segment of industries and may not identify broader intersectoral changes or cover the range of potentially hazardous materials. The counterargument is that many of these products are widely used and thus have economy-wide impacts, and since their production is capital-intensive and generally immobile, governments can better monitor their activities and adapt reporting requirements to local conditions. This paper demonstrates the potential insights that may be gained from combining information collected by these programs with other sources, such as trade data, which in turn can aid policymakers gain a better understanding of the efficacy of regulation as well as promote coordination in environmental standards. 


\section{References}

Antweiler, Werner, Brian R. Copeland, and M. Scott Taylor, "Is free trade good for the environment?" American Economic Review, 91 (September 2001), 877-908.

Becker, Randy and Vernon Henderson, "Effects of air quality regulations on polluting industries," Journal of Political Economy, 108 (April 2000), 379-421.

Bennear, Lori Snyder, "What do we really know? The effect of reporting thresholds on inferences using environmental right-to-know data," Regulation and Governance, 2 (2008), 293-315.

Bertrand, Marianne, Esther Duflo, and Sendhil Mullainathan, "How much should we trust differences-in-differences estimates?" Quarterly Journal of Economics, 119:1 (February 2004), 249-275.

Birdsall, Nancy and David Wheeler, "Trade policy and industrial pollution in Latin America: where are the pollution havens?" Journal of Environment and Development, 2 (Winter 1993), 137-150.

Broughton, Edward, "The Bhopal disaster and its aftermath: a review," Environmental Health: A Global Access Science Source, 4:6 (May 2005).

Brunnermeier, Smita B. and Arik Levinson, "Examining the evidence on environmental regulations and industry location," Journal of Environment and Development, 13 (March 2004), 6-41.

Bui, Linda, "Public disclosure of private information as a tool for regulating environmental emissions: firm-level responses by petroleum refineries to the Toxics Release Inventory," Center for Economic Studies Discussion Paper, 05-13 (October 2005).

Copeland, Brian R. and M. Scott Taylor, "Trade, growth, and the environment," Journal of Economic Literature, 42 (March 2004), 7-71.

Costantini, Valeria and Francesco Crespi, "Environmental regulation and export dynamics of energy technologies," Ecological Economics, 66 (2008), 447-460.

Costantini, Valeria and Massimiliano Mazzanti, "On the green and innovative side of trade competitiveness? The impact of environmental policies and innovation on EU exports," Research Policy, 41 (2012), 132-153.

Ederington, Josh and Jenny Minier, "Is environmental policy a secondary trade barrier? An empirical analysis," Canadian Journal of Economics, 36 (February 2003), 137-154.

Frankel, Jeffrey A. and Andrew K. Rose, "Is trade good or bad for the environment? Sorting out the causality," Review of Economics and Statistics, 87 (February 2005), 85-91. 
Grossman, Gene M. and Alan B. Krueger, "Environmental impacts of a North American Free Trade Agreement," in The Mexico-U.S. Free Trade Agreement (ed. Peter M. Garber), Cambridge, Massachusetts: MIT Press, 1993.

Hamilton, James T. "Pollution as news: media and stock market reactions to the Toxics Release Inventory data," Journal of Environmental Economics and Management, 28 (January 1995), 98-113.

Hettige, Hemamala, Muthukumara Mani, and David Wheeler, "Industrial pollution in economic development: the environmental Kuznets curve revisited," Journal of Development Economics, 62 (2000), 445-476.

Hibiki, Akira and Shunsuke Managi, "Environmental information provision, market valuation, and firm incentives: An empirical study of the Japanese PRTR system," Land Economics, 86 (May 2010), 382-393.

Kalt, Joseph P. "the impact of domestic environmental regulatory policies on U.S. international competitiveness," in International Competitiveness (eds. A. Michael Spence and Heather A. Hazard), Cambridge, MA: Ballinger Publishing, 1988.

Kerret, Dorit and George M. Gray, "What do we learn from emissions reporting? Analytical considerations and comparison of pollutant release and transfer registers in the United States, Canada, England, and Australia," Risk Analysis, 27:1 (2007), 203-223.

Khanna, Madhu, Wilma Rose H. Quimio, and Dora Bojilova, “Toxics release information: a policy tool for environmental protection," Journal of Environmental Economics and Management, 36 (November 1998), 243266.

Koehler, Dinah A. and John D. Spengler, "The Toxic Release Inventory: fact or fiction? A case study of the primary aluminum industry," Journal of Environmental Management, 85 (October 2007), 296-307.

Konar, Shameek, and Mark A. Cohen, "Information as regulation: the effect of community right to know laws on toxic emissions," Journal of Environmental Economics and Management, 232 (January 1997), 109-124.

Levinson, Arik and M. Scott Taylor, “Unmasking the pollution haven effect," International Economic Review, 49 (February 2008), 223-254.

National Fire Protection Administration, NFPA 704: Standard System for the Identification of the Hazards of Materials for Emergency Response, Quincy, Massachusetts: National Fire Protection Association, 2012.

Porter, Michael E. and Claas van der Linde, "Toward a new conception of the environment-competitiveness relationship," Journal of Economic Perspectives, 9:4 (Fall 1995), 97-118. 
Stern, David I., "The rise and fall of the environmental Kuznets curve," World Development, 32:8 (2004), 14191439.

Taylor, M. Scott, "Unbundling the pollution haven hypothesis," Advances in Economic Analysis and Policy, 4(2), 2004, 1-26. Reprinted in The Economics of Pollution Havens, Don Fullerton (ed.), Edward Elgar Publishing, 2006.

Thomas, John K. and Darrell Fannin, "The transboundary trade of hazardous wastes, 2000-2006," Environmental Justice, 4:1 (2011), 55-62.

Tobey, James A. "The effects of domestic environmental policies on patterns of world trade: an empirical test," Kyklos, 43 (1990), 191-209.

Wheeler, David, "Beyond pollution havens," Global Environmental Politics, 2:2 (May 2002), 1-10. 
Table 1: Traded chemical additions to TRI, annual averages between 1989-2006

\begin{tabular}{|c|c|c|c|c|c|c|c|}
\hline \multirow[t]{2}{*}{ Chemical additions } & \multirow[t]{2}{*}{ TRI Listing } & \multicolumn{4}{|c|}{ Listing Years } & \multicolumn{2}{|c|}{ Pre-Listing Years } \\
\hline & & $\begin{array}{c}\text { Emissions } \\
\text { (thou lbs) }\end{array}$ & $\begin{array}{c}\text { Annual } \\
\text { change }(\%)\end{array}$ & $\begin{array}{l}\text { Imports } \\
\text { (thou \$) }\end{array}$ & $\begin{array}{c}\text { Annual } \\
\text { change }(\%)\end{array}$ & $\begin{array}{l}\text { Imports } \\
\text { (thou \$) }\end{array}$ & $\begin{array}{c}\text { Annual } \\
\text { change }(\%)\end{array}$ \\
\hline chlorodifluoromethane & 1994 & $8,722.8$ & -3.8 & $42,122.8$ & 13.1 & $8,485.7$ & 19.1 \\
\hline ethylidene dichloride & & 32.8 & -4.8 & $31,571.5$ & 2.1 & $12,560.3$ & 49.9 \\
\hline formic acid & & $10,952.7$ & -1.8 & $4,742.6$ & -5.3 & $8,113.8$ & 1.4 \\
\hline malonitrile & & 249.7 & -0.5 & 889.0 & 0.5 & 863.9 & 3.5 \\
\hline Bendiocarb & 1995 & 0.05 & -43.7 & 520.2 & -18.8 & $4,354.0$ & -17.0 \\
\hline bromine & & 352.6 & 13.4 & $1,746.2$ & 4.3 & 369.2 & 2.0 \\
\hline Bromoxynil & & 0.7 & -27.8 & $4,677.0$ & -29.5 & $9,832.4$ & 29.9 \\
\hline 3,3-dichlorobenzidine dihydrochloride & & 1.7 & -8.3 & $24,645.0$ & 7.0 & $5,335.9$ & 54.7 \\
\hline dicyclopentadiene & & 581.8 & -7.0 & $18,759.3$ & 3.8 & $6,350.0$ & -4.3 \\
\hline $\mathrm{N}, \mathrm{N}$-dimethylformamide & & $2,378.4$ & -5.3 & $4,578.2$ & -20.2 & $3,681.1$ & 14.4 \\
\hline dinitrobutyl phenol & & 8.6 & -3.2 & 196.7 & -15.1 & 20.1 & -17.1 \\
\hline Fenthion & & 0.0005 & -25.2 & 278.2 & -44.6 & 190.4 & -5.9 \\
\hline fluorine & & 138.4 & 0.4 & 183.9 & 32.9 & 11.3 & 7.7 \\
\hline alpha-hexachlorocyclohexane & & 0.001 & 46.2 & $2,556.2$ & -20.6 & $3,578.3$ & 15.3 \\
\hline lithium carbonate & & 287.2 & -5.6 & $20,787.4$ & 7.2 & $9,653.3$ & 13.3 \\
\hline methoxone & & 4.2 & -8.9 & $10,559.8$ & 5.0 & $5,858.0$ & -11.3 \\
\hline monuron $^{1}$ & & $\mathrm{n} / \mathrm{a}$ & $\mathrm{n} / \mathrm{a}$ & 14.7 & 28.7 & $10,784.1$ & 32.6 \\
\hline paraquat dichloride & & 5.8 & 2.5 & 291.2 & 11.5 & $1,505.3$ & -51.5 \\
\hline sodium nitrite & & $4,690.0$ & 4.5 & $1,156.5$ & 4.5 & $1,130.5$ & -16.2 \\
\hline tetracycline hydrochloride & & 3.3 & 3.8 & $81,109.3$ & 1.1 & $57,918.2$ & 6.0 \\
\hline tetrabromobisphenol A & 2000 & 662.0 & -15.7 & $1,664.3$ & 17.7 & 584.5 & 27.1 \\
\hline vanadium compounds ${ }^{2}$ & & $59,525.5$ & -9.2 & $21,559.4$ & 43.6 & $6,684.2$ & 8.1 \\
\hline
\end{tabular}

\footnotetext{
${ }^{1}$ No emissions data were reported to the US EPA during listing period.
}

${ }^{2}$ Emissions and percent changes are for the vanadium compounds category; traded values based on the following commodities: vanadate, vanadium chloride, vanadium chloride oxide, vanadium hydride, vanadium oxide, vanadium pentoxide, and vanadium sulfate.

Source: US EPA and CID; see text. 
Table 2: Difference-in-differences results for import values, aggregated series

\begin{tabular}{|c|c|c|c|c|c|c|c|}
\hline \multirow{2}{*}{$\begin{array}{l}\text { DV: Import value (\$ mil) } \\
\text { TRI listing year cohort }\end{array}$} & \multicolumn{3}{|c|}{ Pre-treatment Results } & \multicolumn{4}{|c|}{ Main Results } \\
\hline & 1994 & 1995 & 2000 & 1994 & 1995 & 2000 & All Years \\
\hline TRI listing for chemicals & dropped & dropped & dropped & $\begin{array}{c}7.262 \\
(13.282)\end{array}$ & $\begin{array}{c}9.823 \\
(11.111)\end{array}$ & $\begin{array}{c}12.993 \\
(12.480)\end{array}$ & $\begin{array}{l}10.426 \\
(8.354)\end{array}$ \\
\hline GDP per capita ( $\$$ thou) & $\begin{array}{c}1.950 \\
(1.232)\end{array}$ & $\begin{array}{c}1.523 \\
(0.984)\end{array}$ & $\begin{array}{c}5.754 \\
(4.262)\end{array}$ & $\begin{array}{l}3.781 * \\
(1.935)\end{array}$ & $\begin{array}{c}3.290 * * \\
(1.626)\end{array}$ & $\begin{array}{l}3.459 * \\
(1.796)\end{array}$ & $\begin{array}{c}2.827 * * \\
(1.364)\end{array}$ \\
\hline TRI listing $\cdot$ GDP p.c. (\$ thou) & $\begin{array}{c}0.034 \\
(1.606)\end{array}$ & $\begin{array}{l}-1.335 \\
(0.968)\end{array}$ & $\begin{array}{l}-6.339 \\
(3.913)\end{array}$ & $\begin{array}{l}-3.676^{* *} \\
(1.675)\end{array}$ & $\begin{array}{l}-2.841 * * \\
(1.322)\end{array}$ & $\begin{array}{c}-2.997 * * \\
(1.403)\end{array}$ & $\begin{array}{l}-2.424 * * \\
(1.102)\end{array}$ \\
\hline GDP ( $\$ 100$ bil $)$ & $\begin{array}{c}-7.394^{*} \\
(4.271)\end{array}$ & $\begin{array}{l}-2.296 \\
(1.391)\end{array}$ & $\begin{array}{l}-0.329 \\
(0.785)\end{array}$ & $\begin{array}{c}0.403 \\
(1.867)\end{array}$ & $\begin{array}{c}-0.254 \\
(0.857)\end{array}$ & $\begin{array}{c}-0.196 \\
(1.434)\end{array}$ & $\begin{array}{l}-0.389 \\
(0.521)\end{array}$ \\
\hline Import transport costs $(\$$ mil $)$ & $\begin{array}{c}4.137 * * * \\
(1.350)\end{array}$ & $\begin{array}{l}5.326 * * * \\
(1.694)\end{array}$ & $\begin{array}{l}14.835 * * * \\
(1.572)\end{array}$ & $\begin{array}{l}16.120 * * * \\
(2.498)\end{array}$ & $\begin{array}{l}16.247 * * * \\
(2.496)\end{array}$ & $\begin{array}{l}16.218 * * * \\
(2.477)\end{array}$ & $\begin{array}{l}16.357 * * * \\
(2.487)\end{array}$ \\
\hline Import duties (\$ mil) & $\begin{array}{c}21.292 * * * \\
(2.917)\end{array}$ & $\begin{array}{c}19.631 * * * \\
(3.222)\end{array}$ & $\begin{array}{c}11.711 * * * \\
(3.680)\end{array}$ & $\begin{array}{l}-3.332 \\
(9.977)\end{array}$ & $\begin{array}{c}-3.323 \\
(9.801)\end{array}$ & $\begin{array}{l}-3.339 \\
(9.873)\end{array}$ & $\begin{array}{l}-3.515 \\
(9.772)\end{array}$ \\
\hline Terms of trade (year $2000=100$ ) & $\begin{array}{l}-0.010 \\
(0.023)\end{array}$ & $\begin{array}{l}-0.016 \\
(0.019)\end{array}$ & $\begin{array}{c}0.023 \\
(0.054)\end{array}$ & $\begin{array}{c}0.283 \\
(0.195)\end{array}$ & $\begin{array}{c}0.259 \\
(0.171)\end{array}$ & $\begin{array}{c}0.287 \\
(0.198)\end{array}$ & $\begin{array}{c}0.209 \\
(0.135)\end{array}$ \\
\hline OECD membership & dropped & $\begin{array}{c}4.919 \\
(3.950)\end{array}$ & $\begin{array}{c}13.934 \\
(15.753)\end{array}$ & $\begin{array}{c}25.667 \\
(20.557)\end{array}$ & $\begin{array}{l}17.024^{*} \\
(9.591)\end{array}$ & $\begin{array}{c}18.184 \\
(17.020)\end{array}$ & $\begin{array}{l}11.325^{*} \\
(5.846)\end{array}$ \\
\hline Net TRI effect & $\begin{array}{c}0.079 \\
(3.707)\end{array}$ & $\begin{array}{l}-4.102 \\
(2.975)\end{array}$ & $\begin{array}{l}-17.796 \\
(10.985)\end{array}$ & $\begin{array}{c}-26.696 * * \\
(12.840)\end{array}$ & $\begin{array}{c}-23.834 * * \\
(10.437)\end{array}$ & $\begin{array}{l}-14.443 \\
(9.418)\end{array}$ & $\begin{array}{l}-21.407 * * \\
(8.680)\end{array}$ \\
\hline Treatment / Control groups & $4 / 1$ & $16 / 1$ & $8 / 1$ & $4 / 1$ & $16 / 1$ & $8 / 1$ & $28 / 1$ \\
\hline Panel size & 91 & 128 & 97 & 224 & 353 & 235 & 504 \\
\hline Observations & 444 & 759 & 1,042 & 2,533 & 3,852 & 2.676 & 5,397 \\
\hline Within R-squared & 0.850 & 0.854 & 0.747 & 0.686 & 0.684 & 0.685 & 0.681 \\
\hline F-statistic & $42.11 * * *$ & $26.85 * * *$ & $159.04 * * *$ & $31.20 * * *$ & $28.32 * * *$ & $26.39 * * *$ & $19.08 * * *$ \\
\hline
\end{tabular}

All specifications include trade partner, chemical, and year fixed effects. Control group includes all other chemicals aggregated into a single series by trade partner. Treatment group is by individual chemical (ten-digit HS commodity code) and trade partner. Robust standard errors are in parentheses.

Source: see text. 
Table 3: Difference-in-differences results for import values, individual chemical series

\begin{tabular}{|c|c|c|c|c|c|c|c|}
\hline \multirow{2}{*}{$\begin{array}{l}\text { DV: Import value (\$ thou) } \\
\text { TRI listing year cohort }\end{array}$} & \multicolumn{3}{|c|}{ Pre-treatment Results } & \multicolumn{4}{|c|}{ Main Results } \\
\hline & 1994 & 1995 & 2000 & 1994 & 1995 & 2000 & All Years \\
\hline TRI listing for chemicals & dropped & dropped & dropped & $\begin{array}{c}225.882 \\
(278.659)\end{array}$ & $\begin{array}{c}301.954 \\
(327.053)\end{array}$ & $\begin{array}{c}558.516 \\
(376.986)\end{array}$ & $\begin{array}{l}368.695^{*} \\
(217.810)\end{array}$ \\
\hline GDP per capita ( $\$$ thou) & $\begin{array}{c}6.529 \\
(9.136)\end{array}$ & $\begin{array}{l}-0.023 \\
(7.749)\end{array}$ & $\begin{array}{c}5.074 \\
(26.232)\end{array}$ & $\begin{array}{c}27.674 * * * \\
(8.437)\end{array}$ & $\begin{array}{l}27.435 * * * \\
(8.396)\end{array}$ & $\begin{array}{c}27.424 * * * \\
(8.431)\end{array}$ & $\begin{array}{l}27.166^{* * * *} \\
(8.379)\end{array}$ \\
\hline TRI listing · GDP p.c. (\$ thou) & $\begin{array}{c}32.961 \\
(32.705)\end{array}$ & $\begin{array}{l}-17.643 \\
(55.754)\end{array}$ & $\begin{array}{l}-31.373 \\
(19.895)\end{array}$ & $\begin{array}{c}-67.652 * * * \\
(26.419)\end{array}$ & $\begin{array}{c}-26.337 * * \\
(12.043)\end{array}$ & $\begin{array}{c}-24.646 * * * \\
(7.463)\end{array}$ & $\begin{array}{c}-34.482 * * * \\
(10.024)\end{array}$ \\
\hline GDP ( $\$ 100$ bil) & $\begin{array}{l}-7.394 * \\
(4.271)\end{array}$ & $\begin{array}{l}-64.442 \\
(40.693)\end{array}$ & $\begin{array}{l}-11.807 \\
(13.623)\end{array}$ & $\begin{array}{l}-27.135 \\
(17.619)\end{array}$ & $\begin{array}{l}-25.388 \\
(17.409)\end{array}$ & $\begin{array}{l}-26.762 \\
(17.509)\end{array}$ & $\begin{array}{l}-26.127 \\
(17.241)\end{array}$ \\
\hline Import transport costs $(\$$ thou $)$ & $\begin{array}{c}6.835 * * * \\
(1.350)\end{array}$ & $\begin{array}{l}6.597 * * * \\
(1.314)\end{array}$ & $\begin{array}{l}9.349 * * * \\
(1.136)\end{array}$ & $\begin{array}{l}13.401 * * * \\
(1.713)\end{array}$ & $\begin{array}{c}13.412 * * * \\
(1.714)\end{array}$ & $\begin{array}{l}13.410 * * * \\
(1.715)\end{array}$ & $\begin{array}{l}13.406 * * * \\
(1.712)\end{array}$ \\
\hline Import duties ( $\$$ thou) & $\begin{array}{l}23.324 * * * \\
(2.962)\end{array}$ & $\begin{array}{l}22.444 * * * \\
(3.559)\end{array}$ & $\begin{array}{l}11.777 * * * \\
(1.320)\end{array}$ & $\begin{array}{l}13.840 * * * \\
(3.623)\end{array}$ & $\begin{array}{l}13.764 * * * \\
(3.656)\end{array}$ & $\begin{array}{l}13.845 * * * \\
(3.620)\end{array}$ & $\begin{array}{l}13.730 * * * \\
(3.665)\end{array}$ \\
\hline Terms of trade (year $2000=100)$ & $\begin{array}{l}-0.720 \\
(0.632)\end{array}$ & $\begin{array}{l}-0.752 \\
(0.719)\end{array}$ & $\begin{array}{l}-1.034 \\
(1.212)\end{array}$ & $\begin{array}{c}17.366^{* * *} \\
(4.424)\end{array}$ & $\begin{array}{c}17.218 * * * \\
(4.400)\end{array}$ & $\begin{array}{c}17.366 * * * \\
(4.424)\end{array}$ & $\begin{array}{c}17.063 * * * \\
(4.359)\end{array}$ \\
\hline OECD membership & dropped & $\begin{array}{l}100.401 \\
(89.942)\end{array}$ & $\begin{array}{c}58.299 \\
(69.547)\end{array}$ & $\begin{array}{c}430.999 * * * \\
(111.781)\end{array}$ & $\begin{array}{c}415.809 * * * \\
(110.725)\end{array}$ & $\begin{array}{c}422.443 * * * \\
(111.425)\end{array}$ & $\begin{array}{c}412.673 * * * \\
(109.543)\end{array}$ \\
\hline Net TRI effect & $\begin{array}{c}135.089 \\
(134.041)\end{array}$ & $\begin{array}{c}-76.806 \\
(242.720)\end{array}$ & $\begin{array}{l}-163.043 \\
(103.395)\end{array}$ & $\begin{array}{c}-776.679 * * \\
(336.479)\end{array}$ & $\begin{array}{c}-88.803 \\
(238.164)\end{array}$ & $\begin{array}{c}193.443 \\
(373.342)\end{array}$ & $\begin{array}{l}-143.410 \\
(182.870)\end{array}$ \\
\hline Treatment / Control groups & $4 / 638$ & $16 / 638$ & $8 / 638$ & $4 / 638$ & $16 / 638$ & $8 / 638$ & $28 / 638$ \\
\hline Panel size & 4,997 & 5,034 & 5,003 & 14,505 & 14,634 & 14,516 & 14,785 \\
\hline Observations & 24,876 & 30,067 & 54,708 & 156,048 & 157,367 & 156,191 & 158,912 \\
\hline Within R-squared & 0.770 & 0.738 & 0.407 & 0.464 & 0.464 & 0.465 & 0.464 \\
\hline F-statistic & $16.83 * * *$ & $9.16^{* * *}$ & $99.87 * * *$ & $23.78 * * *$ & $23.94 * * *$ & $23.84 * * *$ & $23.93 * * *$ \\
\hline
\end{tabular}

All specifications include trade partner, chemical, and year fixed effects. Control and treatment groups are by individual chemical (ten-digit HS commodity code) and trade partner. Robust standard errors are in parentheses.

Source: see text. 
Table 4: Difference-in-differences results for export values, aggregated series

\begin{tabular}{|c|c|c|c|c|c|c|}
\hline \multirow{2}{*}{$\begin{array}{l}\text { DV: Import value (\$ mil) } \\
\text { TRI listing year cohort }\end{array}$} & \multicolumn{3}{|c|}{ Pre-treatment Results } & \multicolumn{3}{|c|}{ Main Results } \\
\hline & 1994 & 1995 & 2000 & 1994 & 1995 & 1994,1995 \\
\hline TRI listing for chemicals & dropped & dropped & dropped & $\begin{array}{c}-33.800 * * \\
(16.125)\end{array}$ & $\begin{array}{c}-38.647 * * \\
(18.921)\end{array}$ & $\begin{array}{l}-28.532 * \\
(14.646)\end{array}$ \\
\hline GDP per capita ( $\$$ thou) & $\begin{array}{l}-0.633 \\
(4.411)\end{array}$ & $\begin{array}{c}5.117 \\
(4.937)\end{array}$ & $\begin{array}{c}12.422 * * \\
(4.887)\end{array}$ & $\begin{array}{l}5.364 * * \\
(2.572)\end{array}$ & $\begin{array}{c}4.572 * * \\
(2.159)\end{array}$ & $\begin{array}{c}4.352 * * \\
(1.924)\end{array}$ \\
\hline TRI listing $\cdot$ GDP p.c. (\$ thou) & $\begin{array}{c}0.692 \\
(5.396)\end{array}$ & $\begin{array}{l}-5.967 \\
(5.131)\end{array}$ & $\begin{array}{c}-15.814 * * * \\
(5.124)\end{array}$ & $\begin{array}{c}-6.949 * * * \\
(2.302)\end{array}$ & $\begin{array}{c}-5.015 * * * \\
(1.743)\end{array}$ & $\begin{array}{c}-4.346 * * * \\
(1.524)\end{array}$ \\
\hline GDP ( $\$ 100$ bil $)$ & $\begin{array}{l}4.086 \\
(9.663)\end{array}$ & $\begin{array}{c}3.904 \\
(3.210)\end{array}$ & $\begin{array}{c}12.385^{* *} \\
(5.680)\end{array}$ & $\begin{array}{l}17.307^{*} \\
(9.582)\end{array}$ & $\begin{array}{l}10.594 \\
(6.439)\end{array}$ & $\begin{array}{c}7.060 \\
(4.549)\end{array}$ \\
\hline Terms of trade (year $2000=100)$ & $\begin{array}{c}0.013 \\
(0.026)\end{array}$ & $\begin{array}{c}0.009 \\
(0.027)\end{array}$ & $\begin{array}{c}0.018 \\
(0.079)\end{array}$ & $\begin{array}{l}-0.071 \\
(0.134)\end{array}$ & $\begin{array}{l}-0.063 \\
(0.121)\end{array}$ & $\begin{array}{l}-0.054 \\
(0.087)\end{array}$ \\
\hline OECD membership & dropped & $\begin{array}{c}21.111 \\
(23.700)\end{array}$ & $\begin{array}{c}83.639 \\
(81.363)\end{array}$ & $\begin{array}{c}172.716 \\
(125.084)\end{array}$ & $\begin{array}{l}103.047 \\
(78.351)\end{array}$ & $\begin{array}{c}72.856 \\
(56.893)\end{array}$ \\
\hline Net TRI effect & $\begin{array}{c}1.632 \\
(12.725)\end{array}$ & $\begin{array}{l}-17.416 \\
(14.977)\end{array}$ & $\begin{array}{c}-49.507 * * * \\
(16.039)\end{array}$ & $\begin{array}{c}-82.954 * * * \\
(25.130)\end{array}$ & $\begin{array}{c}-80.979 * * * \\
(26.777)\end{array}$ & $\begin{array}{c}-64.640 * * * \\
(21.695)\end{array}$ \\
\hline Treatment / Control groups & $3 / 1$ & $6 / 1$ & $2 / 1$ & $3 / 1$ & $6 / 1$ & $9 / 1$ \\
\hline Panel size & 183 & 236 & 118 & 364 & 478 & 676 \\
\hline Observations & 897 & 1,387 & 1,264 & 4.499 & 5,869 & 8,397 \\
\hline Within R-squared & 0.009 & 0.064 & 0.200 & 0.159 & 0.114 & 0.086 \\
\hline F-statistic & 1.06 & 1.53 & $3.25 * * *$ & $2.46 * * *$ & $2.04 * * *$ & $1.58 * *$ \\
\hline
\end{tabular}

All specifications include trade partner, chemical, and year fixed effects. Control group includes all other chemicals aggregated into a single series by trade partner. Treatment group is by individual chemical (ten-digit HS commodity code) and trade partner. Robust standard errors are in parentheses.

Source: see text. 
Table 5: Difference-in-differences results for export values, individual chemical series

\begin{tabular}{|c|c|c|c|c|c|c|}
\hline \multirow{2}{*}{$\begin{array}{l}\text { DV: Import value (\$ thou) } \\
\text { TRI listing year cohort }\end{array}$} & \multicolumn{3}{|c|}{ Pre-treatment Results } & \multicolumn{3}{|c|}{ Main Results } \\
\hline & 1994 & 1995 & 2000 & 1994 & 1995 & 1994,1995 \\
\hline TRI listing for chemicals & dropped & dropped & dropped & $\begin{array}{c}166.800 \\
(223.057)\end{array}$ & $\begin{array}{c}-153.534 * * * \\
(51.603)\end{array}$ & $\begin{array}{l}-27.746 \\
(94.539)\end{array}$ \\
\hline GDP per capita ( $\$$ thou) & $\begin{array}{c}-4.974 \\
(10.246)\end{array}$ & $\begin{array}{c}2.138 \\
(8.945)\end{array}$ & $\begin{array}{c}14.446^{* *} \\
(6.327)\end{array}$ & $\begin{array}{l}-2.238 \\
(5.503)\end{array}$ & $\begin{array}{c}-2.176 \\
(5.484)\end{array}$ & $\begin{array}{l}-1.913 \\
(5.465)\end{array}$ \\
\hline TRI listing $\cdot$ GDP p.c. (\$ thou) & $\begin{array}{c}624.145 \\
(466.427)\end{array}$ & $\begin{array}{l}-12.701 \\
(11.054)\end{array}$ & $\begin{array}{l}-52.085 * * * \\
(13.793)\end{array}$ & $\begin{array}{c}-0.807 \\
(21.939)\end{array}$ & $\begin{array}{c}-29.357 * * * \\
(6.841)\end{array}$ & $\begin{array}{c}-20.636^{* *} \\
(8.732)\end{array}$ \\
\hline GDP ( $\$ 100$ bil $)$ & $\begin{array}{c}37.579 \\
(55.537)\end{array}$ & $\begin{array}{c}54.418 \\
(37.493)\end{array}$ & $\begin{array}{c}76.517 * * * \\
(13.177)\end{array}$ & $\begin{array}{l}141.256 * * * \\
(23.387)\end{array}$ & $\begin{array}{l}139.075 * * * \\
(23.242)\end{array}$ & $\begin{array}{l}139.954 * * * \\
(23.124)\end{array}$ \\
\hline Terms of trade (year $2000=100$ ) & $\begin{array}{c}0.264 \\
(0.298)\end{array}$ & $\begin{array}{c}0.302 \\
(0.318)\end{array}$ & $\begin{array}{c}0.742 * * \\
(0.367)\end{array}$ & $\begin{array}{l}-0.978 \\
(0.828)\end{array}$ & $\begin{array}{l}-0.970 \\
(0.825)\end{array}$ & $\begin{array}{l}-0.972 \\
(0.819)\end{array}$ \\
\hline OECD membership & dropped & $\begin{array}{c}324.401 * * * \\
(121.751)\end{array}$ & $\begin{array}{c}550.038 * * * \\
(155.352)\end{array}$ & $\begin{array}{c}1335.139 * * * \\
(361.338)\end{array}$ & $\begin{array}{c}1328.047 * * * \\
(359.064)\end{array}$ & $\begin{array}{l}1316.552 * * * \\
(356.812)\end{array}$ \\
\hline Net TRI effect & $\begin{array}{c}1836.420 \\
(1372.367)\end{array}$ & $\begin{array}{l}-39.530 \\
(34.403)\end{array}$ & $\begin{array}{l}-194.334 * * * \\
\quad(51.464)\end{array}$ & $\begin{array}{l}159.415 \\
(283.629)\end{array}$ & $\begin{array}{l}-422.443 * * * \\
\quad(69.977)\end{array}$ & $\begin{array}{l}-216.604 * \\
(114.684)\end{array}$ \\
\hline Treatment / Control groups & $3 / 458$ & $6 / 458$ & $2 / 458$ & $3 / 458$ & $6 / 458$ & $9 / 458$ \\
\hline Panel size & 14,932 & 14,985 & 14,867 & 29,039 & 29,153 & 29,351 \\
\hline Observations & 73,123 & 88,014 & 159,650 & 362,903 & 364,273 & 366,801 \\
\hline Within R-squared & 0.002 & 0.001 & 0.004 & 0.007 & 0.007 & 0.007 \\
\hline F-statistic & $1.75^{*}$ & $4.47 * * *$ & $7.46 * * *$ & $8.30 * * *$ & $8.29 * * *$ & $8.26 * * *$ \\
\hline
\end{tabular}

All specifications include trade partner, chemical, and year fixed effects. Control and treatment groups are by individual chemical (ten-digit HS commodity code) and trade partner. Robust standard errors are in parentheses.

Source: see text. 
Table 6: Serial correlation robustness check for import values, individual chemical series

\begin{tabular}{|c|c|c|c|c|c|c|}
\hline \multirow{2}{*}{$\begin{array}{l}\text { DV: Import value (\$ thou) } \\
\text { TRI listing year cohort }\end{array}$} & \multicolumn{3}{|c|}{ Pre-treatment Period Results } & \multicolumn{3}{|c|}{ Two-Period Results } \\
\hline & 1994 & 1995 & 2000 & 1994 & 1995 & 2000 \\
\hline TRI listing for chemicals & $\begin{array}{c}48.892 \\
(851.268)\end{array}$ & $\begin{array}{c}74.473 \\
(825.722)\end{array}$ & $\begin{array}{c}317.561 \\
(737.046)\end{array}$ & $\begin{array}{l}-428.903 * \\
(223.002)\end{array}$ & $\begin{array}{c}479.408 \\
(433.958)\end{array}$ & $\begin{array}{l}1179.365^{*} \\
(639.359)\end{array}$ \\
\hline GDP per capita ( $\$$ thou) & $\begin{array}{c}19.936 \\
(35.447)\end{array}$ & $\begin{array}{c}16.009 \\
(27.662)\end{array}$ & $\begin{array}{c}4.781 \\
(10.716)\end{array}$ & $\begin{array}{l}-16.772 \\
(11.248)\end{array}$ & $\begin{array}{l}-11.320 \\
(12.739)\end{array}$ & $\begin{array}{l}-15.101 \\
(38.056)\end{array}$ \\
\hline TRI listing $\cdot$ GDP p.c. (\$ thou) & $\begin{array}{c}3.362 \\
(72.660)\end{array}$ & $\begin{array}{l}-25.209 \\
(40.164)\end{array}$ & $\begin{array}{c}37.008 \\
(73.874)\end{array}$ & $\begin{array}{l}28.883 * \\
(15.570)\end{array}$ & $\begin{array}{l}-28.748 \\
(29.015)\end{array}$ & $\begin{array}{l}-76.239 * * \\
(35.419)\end{array}$ \\
\hline GDP ( $\$ 100$ bil $)$ & $\begin{array}{c}465.364 \\
(1244.485)\end{array}$ & $\begin{array}{c}394.101 \\
(1197.655)\end{array}$ & $\begin{array}{l}-42.700 \\
(57.898)\end{array}$ & $\begin{array}{c}-51.954 * * * \\
(19.352)\end{array}$ & $\begin{array}{c}-43.837 * * \\
(19.374)\end{array}$ & $\begin{array}{l}-34.255 \\
(25.785)\end{array}$ \\
\hline Import transport costs $(\$$ thou $)$ & $\begin{array}{c}4.131 * * * \\
(0.187)\end{array}$ & $\begin{array}{l}5.234 * * * \\
(0.172)\end{array}$ & $\begin{array}{l}8.189 * * * \\
(0.163)\end{array}$ & $\begin{array}{c}15.482 * * * \\
(2.983)\end{array}$ & $\begin{array}{l}13.391 * * * \\
(2.103)\end{array}$ & $\begin{array}{l}13.902 * * * \\
(2.223)\end{array}$ \\
\hline Import duties ( $\$$ thou) & $\begin{array}{c}25.027 * * * \\
(0.129)\end{array}$ & $\begin{array}{c}25.170 * * * \\
(0.119)\end{array}$ & $\begin{array}{c}34.885 * * * \\
(0.249)\end{array}$ & $\begin{array}{c}13.137 * * * \\
(2.730)\end{array}$ & $\begin{array}{c}14.554 * * * \\
(2.295)\end{array}$ & $\begin{array}{c}21.381 * * \\
(8.747)\end{array}$ \\
\hline Terms of trade (year $2000=100$ ) & $\begin{array}{c}4.392 \\
(14.084)\end{array}$ & $\begin{array}{c}4.083 \\
(14.692)\end{array}$ & $\begin{array}{c}0.235 \\
(20.764)\end{array}$ & $\begin{array}{c}15.482 * * * \\
(2.983)\end{array}$ & $\begin{array}{c}19.334 * * * \\
(3.926)\end{array}$ & $\begin{array}{c}41.547 * * * \\
(11.223)\end{array}$ \\
\hline OECD membership & $\begin{array}{l}-134.928 \\
(430.933)\end{array}$ & $\begin{array}{c}-75.183 \\
(358.908)\end{array}$ & $\begin{array}{c}-5.154 \\
(239.366)\end{array}$ & $\begin{array}{l}418.920 * * * \\
\quad(94.512)\end{array}$ & $\begin{array}{c}500.267 * * * \\
(102.979)\end{array}$ & $\begin{array}{l}1763.141 * * * \\
(562.504)\end{array}$ \\
\hline Net TRI effect & $\begin{array}{c}62.816 \\
(898.493)\end{array}$ & $\begin{array}{c}-36.501 \\
(842.700)\end{array}$ & $\begin{array}{c}511.921 \\
(797.222)\end{array}$ & $\begin{array}{c}-2.409 \\
(115.611)\end{array}$ & $\begin{array}{c}46.847 \\
(183.017)\end{array}$ & $\begin{array}{c}-59.083 \\
(291.957)\end{array}$ \\
\hline Treatment / Control groups & $4 / 638$ & $16 / 638$ & $8 / 638$ & $4 / 638$ & 17 / 638 & $8 / 638$ \\
\hline Panel size & pooled & pooled & pooled & 21,006 & 21,166 & 20,992 \\
\hline Observations & 7.470 & 7,518 & 7,467 & 28,476 & 28,684 & 28,459 \\
\hline Within R-squared & 0.865 & 0.884 & 0.798 & 0.749 & 0.745 & 0.716 \\
\hline F-statistic & $67.95 * * *$ & $80.40 * * *$ & $42.26 * * *$ & $57.71 * * *$ & $61.30 * * *$ & $30.43 * * *$ \\
\hline
\end{tabular}

Significance level: * 10 percent $* * 5$ percent $* * * 1$ percent

All specifications include trade partner, chemical, and period fixed effects (in two-period specifications). Control and treatment groups are by individual chemical (ten-digit HS commodity code) and trade partner. Robust standard errors are in parentheses.

Source: see text. 
Table 7: Serial correlation robustness check for export values, individual chemical series

\begin{tabular}{|c|c|c|c|c|c|}
\hline \multirow{2}{*}{$\begin{array}{l}\text { DV: Import value (\$ thou) } \\
\text { TRI listing year cohort }\end{array}$} & \multicolumn{3}{|c|}{ Pre-treatment Period Results } & \multicolumn{2}{|c|}{ Two-Period Results } \\
\hline & 1994 & 1995 & 2000 & 1995 & 2000 \\
\hline TRI listing for chemicals & $\begin{array}{l}-292.055 \\
(264.647)\end{array}$ & $\begin{array}{c}-63.592 \\
(337.860)\end{array}$ & $\begin{array}{c}-98.250 \\
(411.502)\end{array}$ & $\begin{array}{c}-360.577 * * * \\
(69.503)\end{array}$ & $\begin{array}{c}555.203 * * * \\
(165.425)\end{array}$ \\
\hline GDP per capita ( $\$$ thou) & $\begin{array}{c}-0.617 \\
(13.120)\end{array}$ & $\begin{array}{c}-0.911 \\
(12.457)\end{array}$ & $\begin{array}{c}-4.927 \\
(10.629)\end{array}$ & $\begin{array}{c}-0.614 \\
(10.829)\end{array}$ & $\begin{array}{c}79.668 * * * \\
(25.423)\end{array}$ \\
\hline TRI listing · GDP p.c. (\$ thou) & $\begin{array}{l}134.739 * * \\
(58.919)\end{array}$ & $\begin{array}{l}-44.171 \\
(42.200)\end{array}$ & $\begin{array}{l}-32.356 \\
(70.145)\end{array}$ & $\begin{array}{r}-14.126 \\
(8.613)\end{array}$ & $\begin{array}{c}-7.551 \\
(11.685)\end{array}$ \\
\hline GDP (\$100 bil) & $\begin{array}{l}105.461 \\
(68.102)\end{array}$ & $\begin{array}{l}111.197 * \\
(64.999)\end{array}$ & $\begin{array}{c}0.002 \\
(36.106)\end{array}$ & $\begin{array}{l}132.660 * * * \\
(19.600)\end{array}$ & $\begin{array}{l}232.575 * * * \\
(32.424)\end{array}$ \\
\hline Terms of trade $($ year $2000=100)$ & $\begin{array}{l}-2.395 \\
(4.007)\end{array}$ & $\begin{array}{l}-2.560 \\
(4.499)\end{array}$ & $\begin{array}{l}-5.951 \\
(7.120)\end{array}$ & $\begin{array}{c}7.217 * * * \\
(2.351)\end{array}$ & $\begin{array}{l}1.554 * * \\
(0.760)\end{array}$ \\
\hline OECD membership & $\begin{array}{l}-134.748 \\
(158.555)\end{array}$ & $\begin{array}{l}-135.476 \\
(167.661)\end{array}$ & $\begin{array}{l}-103.804 \\
(186.555)\end{array}$ & $\begin{array}{l}2050.226^{* * * *} \\
(419.205)\end{array}$ & $\begin{array}{c}775.849 \\
(491.394)\end{array}$ \\
\hline Net TRI effect & $\begin{array}{l}129.151 \\
(269.390)\end{array}$ & $\begin{array}{l}-209.848 \\
(333.037)\end{array}$ & $\begin{array}{l}-226.532 \\
(362.879)\end{array}$ & $\begin{array}{l}-505.452 * * * \\
(89.737)\end{array}$ & $\begin{array}{c}-639.806^{* * * *} \\
(117.575)\end{array}$ \\
\hline Treatment / Control groups & $3 / 458$ & $6 / 458$ & $2 / 458$ & $6 / 458$ & $2 / 458$ \\
\hline Panel size & pooled & pooled & pooled & 35,664 & 35,384 \\
\hline Observations & 17,405 & 17,469 & 17,331 & 53,133 & 52,715 \\
\hline Within R-squared & 0.160 & 0.156 & 0.168 & 0.027 & 0.015 \\
\hline F-statistic & $7.16^{* * *}$ & $7.00 * * *$ & $7.54 * * *$ & $24.64 * * *$ & $18.50 * * *$ \\
\hline
\end{tabular}

All specifications include trade partner, chemical, and period fixed effects (in two-period specifications). Control and treatment groups are by individual chemical (ten-digit HS commodity code) and trade partner. Robust standard errors are in parentheses.

Source: see text. 


\section{Appendix: Description of traded chemicals added to TRI, 1989-2006}

\begin{tabular}{|c|c|c|c|c|}
\hline & CAS Number & $\begin{array}{l}\text { NFPA Health } \\
\text { Hazard } \\
\text { Rating }^{1}\end{array}$ & $\begin{array}{l}\text { Main import } \\
\text { sources, } \\
1989-2006 \\
\end{array}$ & $\begin{array}{c}\text { Main export } \\
\text { destinations, } \\
1989-2006\end{array}$ \\
\hline $\begin{array}{l}\text { Bendiocarb: colorless or white odorless powder used as a pesticide. Mild eye and skin } \\
\text { irritant. Exposure can cause rapid and severe carbamate poisoning with headache, } \\
\text { dizziness, blurred vision, chest pain, vomiting, diarrhea, convulsion, coma and death. }\end{array}$ & $22781-23-3$ & - & $\begin{array}{l}\text { Taiwan, } \\
\text { United } \\
\text { Kingdom, } \\
\text { Germany }\end{array}$ & $\begin{array}{l}\text { Belgium, } \\
\text { Colombia, } \\
\text { Saudi Arabia }\end{array}$ \\
\hline $\begin{array}{l}\text { bromine: dark reddish-brown liquid or vapor used as a gasoline additive and in fire } \\
\text { retardants, dyes, pharmaceuticals, fumigants, photographic chemicals, and water } \\
\text { purification. Eye, skin, and respiratory irritant. Higher exposure can lead to fluid build- } \\
\text { up in lungs with severe shortness of breath. }\end{array}$ & $7726-95-6$ & 3 & $\begin{array}{l}\text { Israel, United } \\
\text { Kingdom, } \\
\text { Canada }\end{array}$ & $\begin{array}{l}\text { Qatar, Canada, } \\
\quad \text { Japan }\end{array}$ \\
\hline $\begin{array}{l}\text { Bromoxynil: colorless crystalline sold used as a herbicide. Eye and skin irritant and } \\
\text { possible teratogen. Exposure may cause weight loss, fever, vomiting, headache, and } \\
\text { death. }\end{array}$ & $1689-84-5$ & - & $\begin{array}{l}\text { France, United } \\
\text { Kingdom, } \\
\text { Italy }\end{array}$ & $\mathrm{n} / \mathrm{a}$ \\
\hline $\begin{array}{l}\text { chlorodifluoromethane: colorless gas with ethereal odor used as refrigerant and } \\
\text { solvent. Eye, skin, and respiratory irritant. Very high exposure can lead to headache, } \\
\text { nausea, drowsiness, tremors, loss of consciousness, and death. }\end{array}$ & $75-45-6$ & - & $\begin{array}{l}\text { United } \\
\text { Kingdom, } \\
\text { France, Spain }\end{array}$ & $\begin{array}{l}\text { Saudi Arabia, } \\
\text { Canada, } \\
\text { Kuwait }\end{array}$ \\
\hline $\begin{array}{l}\text { 3,3-dichlorobenzidine dihydrochloride: gray to purple crystalline powder used to } \\
\text { make dyes and to cure plastics. Eye, skin, and respiratory irritant and probable } \\
\text { carcinogen. Exposure can lead to headache, dizziness, nausea, vomiting, liver and } \\
\text { kidney damage, and cancers of the liver, breast, and bladder. }\end{array}$ & $612-83-9$ & - & $\begin{array}{l}\text { Japan, South } \\
\text { Korea, India }\end{array}$ & $\mathrm{n} / \mathrm{a}$ \\
\hline $\begin{array}{l}\text { dicyclopentadiene: colorless, crystalline powder with camphoric odor used in } \\
\text { pesticides, paints, varnishes, and other chemicals. Eye, skin, and respiratory irritant. } \\
\text { Acute effects include coughing and shortness of breath while chronic effects include } \\
\text { kidney and lung damage. }\end{array}$ & $77-73-6$ & - & $\begin{array}{l}\text { Japan, Canada, } \\
\text { Brazil }\end{array}$ & $\mathrm{n} / \mathrm{a}$ \\
\hline $\begin{array}{l}\text { N,N-dimethylformamide: colorless to yellow liquid with fishy or ammonia odor used } \\
\text { as a solvent or to make coatings, adhesives, and printing ink. Eye, skin, and respiratory }\end{array}$ & $68-12-2$ & 2 & $\begin{array}{l}\text { Canada, } \\
\text { Brazil, Mexico }\end{array}$ & $\mathrm{n} / \mathrm{a}$ \\
\hline
\end{tabular}


Appendix (cont): Description of traded chemicals added to TRI, 1989-2006

\begin{tabular}{|c|c|c|c|c|}
\hline & CAS Number & $\begin{array}{l}\text { NFPA Health } \\
\text { Hazard } \\
\text { Rating }\end{array}$ & $\begin{array}{l}\text { Main import } \\
\text { sources, } \\
1989-2006\end{array}$ & $\begin{array}{l}\text { Main export } \\
\text { destinations, } \\
1989-2006\end{array}$ \\
\hline $\begin{array}{l}\text { dinitrobutyl phenol: reddish brown solid or viscous orange liquid used as a herbicide. } \\
\text { Eye, skin, and respiratory irritant and probable carcinogen. Exposure may cause } \\
\text { headache, fever, jaundice, damage to liver, kidney, and nervous system, and death. }\end{array}$ & $88-85-7$ & - & $\begin{array}{l}\text { United } \\
\text { Kingdom, } \\
\text { Japan }\end{array}$ & $\mathrm{n} / \mathrm{a}$ \\
\hline $\begin{array}{l}\text { ethylidene dichloride: clear liquid with pleasant odor used in chemical manufacture } \\
\text { and as a solvent, degreaser, and wetting agent. Eye, skin, and respiratory irritant. } \\
\text { Exposure may cause nausea, diarrhea, headache, loss of consciousness, and damage to } \\
\text { liver and kidneys. }\end{array}$ & $75-34-3$ & 2 & $\begin{array}{l}\text { Canada, } \\
\text { Germany, } \\
\text { Brazil }\end{array}$ & $\begin{array}{l}\text { Taiwan, Japan, } \\
\text { Netherlands }\end{array}$ \\
\hline $\begin{array}{l}\text { Fenthion: colorless to brown liquid with faint odor used as an insecticide. Eye, skin, } \\
\text { and respiratory irritant. Exposure can cause rapid, fatal organophosphate poisoning } \\
\text { with headache, sweating, nausea, diarrhea, spasms, and death. }\end{array}$ & $55-38-9$ & - & $\begin{array}{l}\text { Japan, India, } \\
\text { Denmark }\end{array}$ & $\mathrm{n} / \mathrm{a}$ \\
\hline $\begin{array}{l}\text { fluorine: pale yellow or green gas or liquid with sharp odor used as rocket fuel or in } \\
\text { other chemicals. Eye, skin, and respiratory irritant. Exposure can lead to fluid build-up } \\
\text { in lungs, mottled teeth, nosebleeds, nausea, and diarrhea. }\end{array}$ & $7782-41-4$ & - & $\begin{array}{l}\text { China, Japan, } \\
\text { South Korea }\end{array}$ & $\begin{array}{l}\text { Canada, } \\
\text { Germany, } \\
\text { Taiwan }\end{array}$ \\
\hline $\begin{array}{l}\text { formic acid: colorless liquid with strong odor used in textile dyeing and finishing, } \\
\text { leather treatment, and other chemicals. Eye, skin, and respiratory irritant. Exposure can } \\
\text { lead to fluid build-up in lungs, headache, nausea, and kidney damage. }\end{array}$ & $64-18-6$ & 3 & $\begin{array}{l}\text { United } \\
\text { Kingdom, } \\
\text { Germany, } \\
\text { Belgium }\end{array}$ & $\begin{array}{l}\text { Belgium, } \\
\text { Germany, } \\
\text { Ireland }\end{array}$ \\
\hline $\begin{array}{l}\text { alpha-hexachlorocyclohexane: white, yellow, or brown powder in flake or crystals } \\
\text { with a musty odor used as an insecticide. Eye, skin, and respiratory irritant and } \\
\text { probable carcinogen. Exposure may cause headache, nausea, dizziness, seizures, and } \\
\text { convulsions. }\end{array}$ & $319-84-6$ & - & $\begin{array}{l}\text { France, India, } \\
\text { Romania }\end{array}$ & $\begin{array}{l}\text { Israel, } \\
\text { Bulgaria, } \\
\text { Lithuania }\end{array}$ \\
\hline $\begin{array}{l}\text { lithium carbonate: white, odorless powder used in ceramic glazing, varnishes, and } \\
\text { lubricants as well as pharmaceuticals. Eye, skin, and respiratory irritant and teratogen. } \\
\text { May cause fluid build-up in lungs, headache, seizures, coma, and damage to thyroid, } \\
\text { heart, and kidneys. }\end{array}$ & $554-13-2$ & - & $\begin{array}{l}\text { Chile, } \\
\text { Argentina, } \\
\text { New Zealand }\end{array}$ & $\begin{array}{l}\text { Germany, } \\
\text { Japan, United } \\
\text { Kingdom }\end{array}$ \\
\hline
\end{tabular}


Appendix (cont): Description of traded chemicals added to TRI, 1989-2006

\begin{tabular}{|c|c|c|c|c|}
\hline & CAS Number & $\begin{array}{l}\text { NFPA Health } \\
\text { Hazard } \\
\text { Rating }^{1}\end{array}$ & $\begin{array}{l}\text { Main import } \\
\text { sources, } \\
1989-2006\end{array}$ & $\begin{array}{c}\text { Main export } \\
\text { destinations, } \\
1989-2006\end{array}$ \\
\hline $\begin{array}{l}\text { malonitrile: white powder used in chemical manufacturing and gold processing. Eye, } \\
\text { skin, and respiratory irritant. May cause fluid build-up in lungs, headache, nausea, } \\
\text { numbness, lethargy, tremors, and convulsions as well as liver and kidney damage. }\end{array}$ & $109-77-3$ & - & $\begin{array}{l}\text { Switzerland, } \\
\text { China, } \\
\text { Germany }\end{array}$ & $\mathrm{n} / \mathrm{a}$ \\
\hline $\begin{array}{l}\text { methoxone: white crystalline powder used as a herbicide. Severe eye and skin irritant } \\
\text { and possible carcinogen. Exposure can lead to slurred speech, spasms, low-blood } \\
\text { pressure, loss of consciousness, and damage to kidneys, liver, and other organs. }\end{array}$ & $94-74-6$ & 2 & $\begin{array}{l}\text { Netherlands, } \\
\text { United } \\
\text { Kingdom, } \\
\text { Germany }\end{array}$ & $\mathrm{n} / \mathrm{a}$ \\
\hline $\begin{array}{l}\text { monuron: white crystalline powder with faint odor used as a herbicide. Eye, skin, and } \\
\text { respiratory irritant. May lead to nausea, vomiting, diarrhea, headache, emphysema, } \\
\text { weight loss, and damage to liver and kidneys. }\end{array}$ & $150-68-5$ & - & $\begin{array}{l}\text { Israel, Austria, } \\
\text { Hungary }\end{array}$ & $\mathrm{n} / \mathrm{a}$ \\
\hline $\begin{array}{l}\text { paraquat dichloride: colorless to yellow, odorless solid used as a herbicide. Severe } \\
\text { eye, skin, and respiratory irritant and probable carcinogen. Exporsure may lead to fluid } \\
\text { build-up in lungs, nausea, vomiting, diarrhea, and damage to liver, kidneys, and heart. }\end{array}$ & $1910-42-5$ & - & $\begin{array}{l}\text { Japan, } \\
\text { Guatemala, } \\
\text { Taiwan }\end{array}$ & $\mathrm{n} / \mathrm{a}$ \\
\hline $\begin{array}{l}\text { Sodium nitrite: yellowish white and odorless crystalline powder used in metal } \\
\text { treatment, color fixatives, food preservatives, and pharmaceuticals. Eye, skin, and } \\
\text { respiratory irritant. May cause headache, blue lips, nausea, vomiting, diarrhea, } \\
\text { collapse, and death. }\end{array}$ & $7632-00-0$ & - & $\begin{array}{l}\text { Germany, } \\
\text { Poland, United } \\
\text { Kingdom }\end{array}$ & $\mathrm{n} / \mathrm{a}$ \\
\hline $\begin{array}{l}\text { tetrabromobisphenol A: colorless to yellow solid used as a flame retardant. May } \\
\text { cause damage to thyroid. }\end{array}$ & $79-94-7$ & - & $\begin{array}{l}\text { Istael, Japan, } \\
\text { China }\end{array}$ & $\mathrm{n} / \mathrm{a}$ \\
\hline $\begin{array}{l}\text { tetracycline hydrochloride: yellow, odorless powder used in pharmaceuticals. } \\
\text { Exposure may cause anorexia, nausea, diarrhea, black tongue, tooth discoloration, } \\
\text { jaundice, and damage to kidney and liver. }\end{array}$ & $64-75-5$ & - & $\begin{array}{l}\text { China, } \\
\text { Portugal, Italy }\end{array}$ & $\begin{array}{l}\text { Italy, Japan, } \\
\text { Belgium }\end{array}$ \\
\hline $\begin{array}{l}\text { vanadate: white powder used in chemical reactions. Eye, skin, and respiratory irritant. } \\
\text { May cause headache, coughing, diarrhea, green tongue, and tremors. }\end{array}$ & $13721-39-6$ & 2 & $\begin{array}{l}\text { South Africa, } \\
\text { Germany, } \\
\text { France }\end{array}$ & $\mathrm{n} / \mathrm{a}$ \\
\hline
\end{tabular}


Appendix (cont): Description of traded chemicals added to TRI, 1989-2006

\begin{tabular}{|c|c|c|c|c|}
\hline & CAS Number & $\begin{array}{l}\text { NFPA Health } \\
\text { Hazard } \\
\text { Rating }^{1}\end{array}$ & $\begin{array}{l}\text { Main import } \\
\text { sources, } \\
1989-2006 \\
\end{array}$ & $\begin{array}{c}\text { Main export } \\
\text { destinations, } \\
1989-2006\end{array}$ \\
\hline $\begin{array}{l}\text { vanadium chloride: reddish-brown, viscous liquid used in textile dyeing and other } \\
\text { chemical compounds. Eye, skin, and respiratory irritant. May cause fluid build-up in } \\
\text { lungs, green tongue, and liver damage. }\end{array}$ & $7632-51-1$ & 2 & $\begin{array}{c}\text { France, China, } \\
\text { Japan }\end{array}$ & $\mathrm{n} / \mathrm{a}$ \\
\hline $\begin{array}{l}\text { vanadium chloride oxide: yellow liquid with sharp odor used as a chemical catalyst } \\
\text { and dye manufacture. Eye, skin, and respiratory irritant. May cause bronchitis, anemia, } \\
\text { and kidney damage. }\end{array}$ & $7727-18-6$ & - & $\begin{array}{l}\text { Japan, United } \\
\text { Kingdom }\end{array}$ & $\mathrm{n} / \mathrm{a}$ \\
\hline $\begin{array}{l}\text { vanadium hydride: solid used in textile dyeing and neutron moderation during atomic } \\
\text { reactions. Eye, skin, respiratory, and gastrointestinal irritant. May cause headache, } \\
\text { dizziness, fatigue, nausea, loss of consciousness, and death. }\end{array}$ & $13966-93-3$ & 1 & $\begin{array}{l}\text { South Africa, } \\
\text { Gernay, } \\
\text { Russia }\end{array}$ & $\mathrm{n} / \mathrm{a}$ \\
\hline $\begin{array}{l}\text { vanadium oxide: yellow or brown, odorless crystalline solid used as a chemical } \\
\text { catalyst, photography developer, and intermediate in pesticides and dyes. Eye, skin, } \\
\text { and respiratory irritant and probably carcinogen. Exposure can cause headache, } \\
\text { dizziness, nausea, fluid build-up in lungs, and damage to liver and kidneys. }\end{array}$ & $12036-21-4$ & 2 & $\begin{array}{l}\text { South Africa, } \\
\text { Austria, } \\
\text { United } \\
\text { Kingdom }\end{array}$ & $\begin{array}{l}\text { Spain, Austria, } \\
\text { Sweden }\end{array}$ \\
\hline vanadium pentoxide: see vanadium oxide & $1314-62-1$ & 3 & $\begin{array}{l}\text { South Africa, } \\
\text { China, Russia }\end{array}$ & $\begin{array}{l}\text { Belgium, } \\
\text { Germany, } \\
\text { Brazil }\end{array}$ \\
\hline $\begin{array}{l}\text { vanadium sulfate: pale blue, odorless powder used in textile dyes, glass and ceramic } \\
\text { coloring, and other chemical manufacture. Eye, skin, and respiratory irritant. May } \\
\text { cause fluid build-up in lungs, green tongue, and damage to liver and kidneys. }\end{array}$ & $27774-13-6$ & - & $\begin{array}{l}\text { South Africa, } \\
\text { India, } \\
\text { Germany }\end{array}$ & $\mathrm{n} / \mathrm{a}$ \\
\hline
\end{tabular}

${ }^{1}$ NFPA Health Hazard Rating: 1 - Materials that under emergency conditions can cause significant irritation; 2 - Materials that under emergency conditions can cause temporary incapacitation or residual injury; 3 - Materials that under emergicy conditions can cause serious or permanent injury; 4 - Materials that under emergency conditions can be lethal; see NFPA (2012).

Source: State of New Jersey Department of Health, website: http://web.doh.state.nj.us/rtkhsfs/factsheets.aspx; US Occupational Safety and Health Administration, website: http://www.osha.gov/chemicaldata/; US National Library of Medicine, website: http://toxnet.nlm.nih.gov/cgibin/sis/htmlgen?HSDB; and author's calculations. 